\title{
Absence of close linkage between benign hereditary chorea and the locus D4S10 (probe G8)
}

\author{
OLIVER W J QUARRELL, SANDRA YOUNGMAN, MANSOOR SARFARAZI, \\ AND PETER S HARPER \\ From the Institute of Medical Genetics, University of Wales College of Medicine, Heath Park, Cardiff CF4 \\ $4 X N$.
}

SUMmARY A genetic linkage study between benign hereditary chorea and the locus D4S10 using the DNA probe G8 has shown two recombinations in five small families. There were negative lod scores at recombination fractions that show conclusive evidence of linkage in 16 larger British Huntington's disease families. We suggest that although benign hereditary chorea and Huntington's disease may have some clinical similarities they are probably at two different loci.

Benign hereditary chorea is a rare disorder. It was first described in $1967^{12}$ and is characterised by the onset of non-progressive chorea in childhood. There is an absence of mental deterioration, although in one family recently reported the affected subjects had a lower IQ than their unaffected family members. ${ }^{3}$ The pattern of inheritance is thought to be autosomal dominant; male to male transmission is known to occur, ${ }^{45}$ and in reviewing the families reported up to 1975 , Harper $^{6}$ suggested that there is nearly complete penetrance in males but approximately $75 \%$ penetrance in females.

Huntington's disease (HD) is the major autosomal dominant choreiform disorder. It is distinguished from benign hereditary chorea because the onset is usually in adult life, the choreiform movements are progressive, and there is associated personality change and progressive intellectual impairment. The locus for HD has been mapped to the short arm of chromosome 4 using a DNA probe $\mathrm{G} 8{ }^{7-10}$ whose locus has been defined as D4S10." Sixteen British HD families have been studied with the $\mathrm{G} 8$ probe and the results confirm tight linkage. ${ }^{12}$ We have now conducted a similar study with five British benign hereditary chorea families to determine whether this disease locus is also linked to D4S10.

\section{Methods}

The families were all examined clinically and four have been reported previously. Families 1 and 2 were described by Harper, ${ }^{6}$ family 4 in this series is

Received for publication 9 September 1986.

Revised version accepted for publication 16 February 1987. the third family reported by Sleigh and Lindenbaum, ${ }^{3}$ and family 5 has been described by Robinson and Thornett. $^{13}$

DNA was extracted from venous blood by the method of Kunkel et al. ${ }^{1+}$ DNA $(5 \mu \mathrm{g})$ was digested to completion using the appropriate enzyme. Agarose gel electrophoresis, Southern blotting, hybridisation, and autoradiography were carried out by standard methods. Polymorphisms at the D4SIO locus were identified with subclones of the G8 probe. Subclone pK082 detects polymorphisms with HindIII, PstI, and NciI restriction enzymes. Subclone pK083 detects the EcoRI polymorphism and the R7 probe (which overlaps G8) detects a $B g I I$ polymorphism. Genetic linkage was analysed with the computer programme LINKAGE ${ }^{15}$ using the same D4S10 allele frequencies as for the HD study. ${ }^{12}$

\section{Results}

The pedigrees and genotypes are illustrated in fig 1 . The only potential phase known meioses occurred in family 2 which unfortunately was uninformative for both HindIII and EcoRI polymorphisms. Subject II.1 was also homozygous for other polymorphisms identified by the BglI, PstI, and Ncil restriction enzymes.

The polymorphisms identified by the restriction enzymes can be combined to give a complex haplotype at the $D 4 S 10$ locus. ${ }^{12}$ Two definite recombinations have been observed in families 1 and 4 . In family 1 , the normal male in generation III typed $\mathrm{CC}: 22$, establishing the phase $\mathrm{A} 1: \mathrm{C} 2$ in his affected parent and $\mathrm{A} 2: \mathrm{C} 2$ in the unaffected parent. $A$ 
Family 1

I

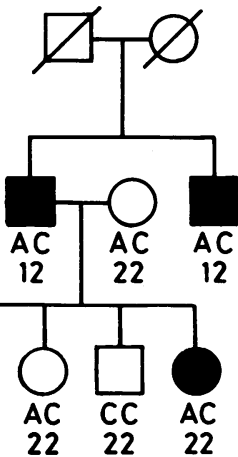

III

12
Family 2

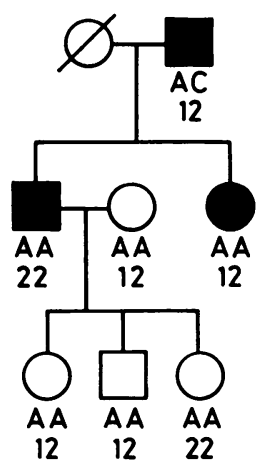

Family 3

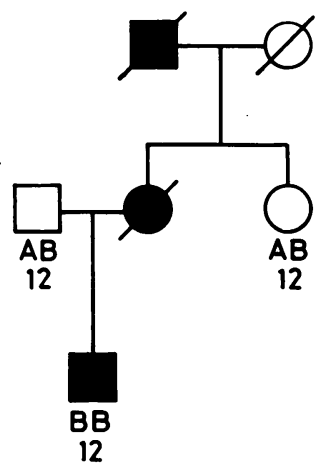

Family 4

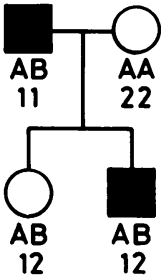

Family 5

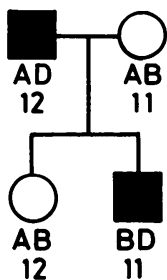

Five benign hereditary chorea families studied with

crossover must have occurred as one sister inherited benign hereditary chorea and genotype Al from her father whereas the other affected sister inherited genotype $\mathrm{C} 2$ with benign hereditary chorea. In family 4 the unaffected parent in generation I typed $\mathrm{AA}: 22$ which establishes the phase $\mathrm{A} 2: \mathrm{B} 1$ in the affected offspring; however, the unaffected daughter has the same genotype so a recombination must have occurred.

The lod score values $(Z)$ for various values of recombination rate $(\theta)$ are shown in table 1 assuming complete penetrance, and in table 2 assuming reduced penetrance in females. It is clear that the recombination events are more clearly demonstrated by the EcoRI polymorphism as these lod scores are negative for greater values of $\theta$. Reducing the penetrance has not significantly altered the results. The maximum positive lod scores are $0 \cdot 034$ and 0.033 at $\theta=0.30$ and $\theta=0.28$ respectively, neither representing significant evidence in favour of linkage.

TABLE 1 Lod scores for values of $\theta$ assuming complete penetrance of benign hereditary chorea.

\begin{tabular}{|c|c|c|c|}
\hline$\theta$ & $\begin{array}{l}\text { HindIII } \\
\text { polymorphism }\end{array}$ & $\begin{array}{l}\text { EcoRI } \\
\text { polymorphism }\end{array}$ & $\begin{array}{l}\text { Combined Hindlll } \\
\text { and EcoRI } \\
\text { polymorphisms }\end{array}$ \\
\hline 0.011 & -0.052 & -1.019 & $-2 \cdot 264$ \\
\hline 0.65 & $-(1) .244$ & $-(1) .361$ & $-(1) .887$ \\
\hline $0 \cdot 10$ & 0.008 & $-0 \cdot 126$ & -01.372 \\
\hline 0.15 & $0 \cdot 102$ & $-(1) \cdot(126$ & $-(0 \cdot 140$ \\
\hline 0.20 & 0.129 & 0.018 & $-(1) \cdot(128$ \\
\hline 0.25 & 0.120 & $0 .(1), 33$ & $(1) \cdot(121$ \\
\hline 0.30 & $(0.093$ & $0 .(1) .30$ & $0 .(1) .34$ \\
\hline 0.35 & $0 .(160)$ & $0 \cdot(1) 22$ & $0 .(1) 99$ \\
\hline 0.40 & $(0 \cdot(1) 29$ & $0 .(1) 1$ & 0.016 \\
\hline 0.45 & 0.008 & $(1) \cdot(0), 3$ & 0.005 \\
\hline
\end{tabular}

TABLE 2 Lod score for values of $\theta$ assuming reduced penetrance of benign hereditary chorea in females.

\begin{tabular}{|c|c|c|c|}
\hline$\theta$ & $\begin{array}{l}\text { HindIII } \\
\text { polymorphism }\end{array}$ & $\begin{array}{l}\text { EcoRI } \\
\text { polymorphism }\end{array}$ & $\begin{array}{l}\text { Combined HindIII } \\
\text { and EcoRI } \\
\text { polymorphisms }\end{array}$ \\
\hline 0.01 & $(0.235$ & -1.209 & $-1 \cdot 171$ \\
\hline 0.05 & 0.268 & -0.534 & -0.459 \\
\hline$(0.10$ & (). 272 & -01.274 & $-(1.180$ \\
\hline (). 15 & $(0.249$ & -0.149 & $-(0.053$ \\
\hline 0.20 & 0.210 & $-0 .(179$ & 0.007 \\
\hline (1).25 & 0.164 & $-(0 \cdot() 40$ & $0 .(129$ \\
\hline 0.30 & 0.115 & -0.018 & 0.0132 \\
\hline 0.35 & $(1) \cdot(1) 70$ & $-(1) \cdot(0) 7$ & 0.024 \\
\hline 0.40 & $(0.0133$ & $-(1 \cdot(x) 2$ & (). $(0) 13$ \\
\hline 0.45 & 0.0109 & $-(1) \cdot(0) 5$ & $0 .(1) 4$ \\
\hline
\end{tabular}

\section{Discussion}

These results are strongly against close linkage between $D 4 S 10$ and benign hereditary chorea but do not completely exclude loose linkage. The form of analysis has not significantly altered the results. Reduced penetrance in males has been suggested by the pedigree of Burns et $a l^{16}$ and by one of the families reported by Sleigh and Lindenbaum, ${ }^{5}$ but in that case the proposed unaffected obligatory male carrier was not examined. Reduced penetrance in males is thus unlikely to affect the outcome of this study as there is only one unaffected male in an informative family (family 1, III.3).

If benign hereditary chorea were closely linked to $D 4 S 10$ then it would be possible to suggest that this disease locus is allelic to the $H D$ locus. Benign hereditary chorea could then be considered as a 'milder' form of HD in a similar manner to that suggested for the $\mathrm{X}$ linked Duchenne and Becker muscular dystrophies, ${ }^{17}$ where linkage studies with DNA markers have proved comparable for the two 
disorders. Close linkage between $D 4 S 10$ and $H D$ is well established: a summary of the linkage data which has been published between $D 4 S 10$ and $H D$ is given in table 3 . The $95 \%$ confidence limit for the linkage between $D 4 S 10$ and $H D$ is tight $(0.4$ to $6 \cdot 3$ $\mathrm{cM})$ and this is illustrated in fig $2 \mathrm{a}$. It would be unreasonable to expect the small benign hereditary chorea families to yield such large lod scores, but the only positive scores observed are small and lie well outside the $95 \%$ confidence limit for HD. In contrast to the HD study, the $95 \%$ confidence limit for linkage between $D 4 S 10$ and benign hereditary chorea is extremely wide $(5$ to $50 \mathrm{cM})$ as illustrated in fig $2 b$. The confidence intervals for these two disorders overlap between 5 and $6.3 \mathrm{cM}$ so the

TABI.E 3 Summary of linkage data between Huntington's disease and D4SIO.

\begin{tabular}{|c|c|c|c|}
\hline & $7 . \max$ & $\theta \max$ & $\begin{array}{l}95 " . " \text { contidence } \\
\text { limil for } \theta\end{array}$ \\
\hline Study $1^{\text {In }}$ & $12 \cdot 14$ & $0 \cdot 12$ & $(1-1) \cdot(1) 76$ \\
\hline Study $2^{\prime \prime}$ & 13.59 & 0.166 & $(1-0) \cdot 120)$ \\
\hline Study $3^{12}$ & $17 \cdot 6$ & 0.12 & $11 \cdot(k 14-1) \cdot(6) 3$ \\
\hline Total & 42.74 & $01 .(14$ & $(1) \cdot(1), 3-(1) \cdot(16,3$ \\
\hline
\end{tabular}

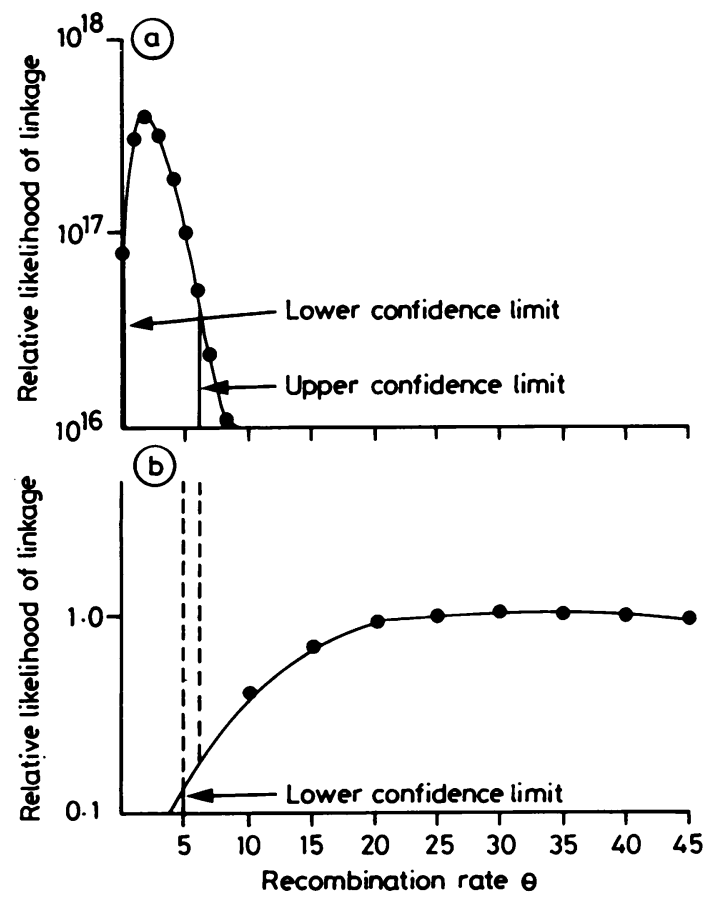

FIG 2 Relative likelihoods of linkage between locus D45IO and (a) Huntington's disease, South Wales study, and (b) benign hereditary chorea, illustrating the small overlap between $95 \%$ confidence intervals. possibility that these disease loci are allelic has not been completely excluded. This explanation seems unlikely on the basis that two recombinations have been observed in nine phase unknown meioses from five benign hereditary chorea families, whereas the same number of recombinations were observed in 16 much larger HD families. We therefore suggest that the two diseases are the result of mutations at different loci, but this hypothesis needs to be tested further on additional families with benign hereditary chorea.

We would like to thank Professor N Nevin (Belfast) for the gift of DNA samples from family 2 and $\mathrm{Dr}$ James Gusella (Boston) for the gift of the DNA probes. We also thank Dr G Sleigh (Oxford) and Dr R Robinson (London) for allowing us to visit and examine their patients. This work has been supported by a grant from the Medical Research Council.

\section{References}

${ }^{1}$ Haerer AF, Currier RD, Jackson JF. Hereditary non progressive chorea of early onset. $N$ Engl J Med 1967:276:122()-4.

2 Pincus JH, Chutorian A. Familial benign chorea with intention tremor: a clinical entity. J Pediatr 1967;70:724-9.

${ }^{3}$ Leli DA, Furlow TW, Falgout JC. Benign familial chorea: an association with intellectual impairment. J Neurol Neurosurg Psychiatry 1984;47:471-4.

4 Sandjapour K, Amato K. Hereditary non-progressive chorea of early onset - a new entity? Adv Neurol 1973;1:79-91.

5 Sleigh G, Lindenbaum RH. Benign (non-paroxysmal) familial chorea. Paediatric perspectives. Arch Dis Child 1981;56:616-21.

${ }^{\circ}$ Harper PS. Benign hereditary chorea, clinical and genetic aspects. Clin Genet 1978:13:85-95.

${ }^{7}$ Gusella JF, Wexler NS, Conneally PM, et al. A polymorphic DNA marker genetically linked to Huntington's disease. Nature 1983;306:234-8.

${ }^{x}$ Folstein S, Phillips J, Mycrs D, et al. Huntington's disease: two families with differing clinical features show linkage to the G8 probc. Science 1985;229:776-9.

" Harper PS, Youngman S, Anderson MA, et al. Genetic linkage between Huntington's disease and the DNA polymorphism G8 in South Wales families. J Med Genet 1985:22:447-50.

11) Gusella JF. Tanzi RE, Bader PI, et al. Deletion of the Huntington's disease linked G8 (D4S10) locus in Wolf Hirschhorn syndrome. Nature 1985;318:75-8.

$"$ Human Gene Mapping 7. Report of the committec on chromosomes 2-5. Cytogenet Cell Genet 1984;37:22-46.

12 Youngman S, Sarfarazi M, Quarrell OWJ, et al. Studies of a DNA marker (G8) genetically linked to Huntington's disease in British families. Hum Genet 1986;73:333-9.

13 Robinson RO, Thornett CEE. Benign hereditary chorea response to steroids. Dev Med Child Neurol 1985;27:814-6.

${ }^{14}$ Kunkel LM. Smith KD. Boyer SH. et al. Analysis of human Y-chromosome-specific reiterated DNA in chromosome variants. Proc Natl Acad Sci USA 1977:74:1245-9.

15 Lathrop GM, Laloucl JM, Julicr C. Ott J. Stratcgies for multi locus linkage analysis in humans. Proc Natl Acad Sci USA 1984;81:3443-6.

${ }^{16}$ Burns J, Neuhauser G, Thomas IL. Benign hereditary chorea. Non-progressive chorea of early onset. Clinical genetics of the syndrome and report of a new family. Neuropadiatrie 1976;7:431-8.

17 Kingston HM, Sarfarazi M. Thomas NST, Harper PS. Localisa- 
tion of Becker muscular dystrophy gene on the short arm of the $\mathrm{X}$ chromosome by linkage to cloned DNA sequences. Hum Genet 1984;67:6-17.

${ }^{18}$ Human Gene Mapping 8. Report of the committee on chromosome 3-4. Cytogenet Cell Genet 1985;40:107-27.
Correspondence and requests for reprints to $\mathrm{Dr} \stackrel{?}{\Rightarrow}$ O W J Quarrell, Institute of Medical Genetics, $\stackrel{\vec{D}}{\vec{D}}$ University of Wales College of Medicine, Heath Park, Cardiff CF4 4XN.

\section{Announcements}

FIFTH INTERNATIONAL CLINICAL GENETICS SEMINAR

The Fifth International Clinical Genetics Seminar will be held in Rethymno, Crete on 25 to 30 October 1988. Main themes of the Seminar are 'Genetics of Kidney Disorders' and 'Genetics of Neuromuscular Disorders'. For futher information write to Dr C Bartsocas, "P and A Kyriakou" Children's Hospital, GR-11527 Athens, Greece.
FIFTH INTERNATIONAL RETINITIS PIGMENTOSA CONGRESS

The Fifth International Retinitis Pigmentosa Congress will be held in Melbourne, Australia on 4 to 7 o November 1988. For further details contact Leonie Kelleher, Congress Convenor, 46A Oxley Road, $\stackrel{\triangleright}{\unrhd}$ Hawthorn, Victoria 3122, Australia. Tel: (03) $819 \overrightarrow{\vec{B}}$ 6590 . 